African Crop Science Journal by African Crop Science Society is licensed under a Creative Commons Attribution 3.0 Uganda License. Based on a work at www.ajol.info/ and www.bioline.org.br/cs DOI: http://dx.doi.org/10.4314/acsj.v25i3.5

\title{
AQUEOUS PLANT EXTRACTS FOR CONTROL OF GROUNDNUT LEAF SPOT IN BURKINA FASO
}

\author{
K. KOÏTA, B. M'Bi ZAGRE ${ }^{1}$ and P. SANKARA \\ Department of Biology and Physiology Vegetal, Biosciences Laboratory, UniversitéOuaga I Pr Joseph KI- \\ ZERBO, 03 BP 7021 Ouagadougou 03, Burkina Faso \\ ${ }^{1}$ Institut de l'Environnement et de Recherches Agricoles (INERA), Département Productions Végétales \\ 04 BP 8645 Ouagadougou 04, Burkina Faso \\ Corresponding author: benbakadi@yahoo.fr, koita.kadidia@yahoo.fr
}

(Received 11 October, 2016; accepted 8 August, 2017)

\begin{abstract}
Early and late leaf spots, the two fungal diseases of groundnut (Arachis hypogaea L.) caused by Cercospora arachidicola Hori. and Phaeoisariopsis personata (Berk and Curt), respectively, cause severe groundnut crop losses in arid zone of West Africa. The objective of this study was to evaluate efficacy of aqueous extracts of four native plants species of Burkina (Lippia multiflora Moldenke, Boscia senegalensis (Pers.) Lam, Ziziphus mucronata Willd. and Securidaca longepedonculata L) against these diseases, on a susceptible groundnut variety (TS32-1) in the field during the cropping seasons of 2010 to 2012, in Gampela district in Burkina Faso. The four extracts ( $50 \mathrm{~g}$ dry weight per liter of distilled water) were sprayed by using a manual sprayer (Solo). Disease incidence and severity, defoliation rate, necrotic leaf area, pod yield, and 100 seed weight were evaluated. Disease score which attests to the severity of parasitic attack was done following ICRISAT's disease score scale, which ranges from 1 to 9. Treatments with aqueous extracts of L. multiflora and Z. mucronata recorded the best disease control. The disease scores of these treatments were less or equal to 4 (corresponding to a resistance of plants), and increased pod yield by $2676.889 \mathrm{~kg} \mathrm{ha}^{-1}$ (L. multiflora) and $2976.926 \mathrm{~kg} \mathrm{ha}^{-1}$ (Z. mucronata), respectively. This field trial has confirmed that plants tested significantly control leaf spot diseases of groundnut.
\end{abstract}

Key Words: Arachis hypogaea, Cercospora arachidicola, Phaeoisariopsis personata

\section{RÉSUMÉ}

Les cercosporioses précoce et tardive, deux maladies fongiques de l'arachide causées respectivement par Cercospora arachidicola Hori. et Phaeoisariopsis personata (Berk and Curt), provoquent d'importantes pertes de production dans la zone aride ouest Africaine. L'objectif de cette étude est d'évaluer l'efficacité antifongique de quatre plantes du Burkina Faso (Lippia multiflora Moldenke, Boscia senegalensis (Pers.) Lam, Ziziphus mucronata Willd. et Securidaca longepedonculata L) contre ces maladies sur une variété sensible d'arachide au champ. L'étude conduite pendant les saisons hivernales de 2010 à 2012 à Gampela (Burkina Faso) a permis d'évaluer les paramètres suivants : incidence de la maladie, taux de défoliation, surface foliaire nécrosée, rendement graine et poids de 100 graines. La notation de l'incidence de la maladie a été faite suivant une échelle à 9 classes de I'ICRISAT. Les traitements aux extraits de L. multiflora et de $Z$. mucronata ont induit la plus forte réduction de l'incidence parasitaire. Les notes de maladie enregistrées ont été inférieures ou égales à la note 4 dans ces parcelles avec un rendement graine allant de $2676.889 \mathrm{~kg} \mathrm{ha}^{-1}$ (L. multiflora) et de $2976.926 \mathrm{~kg}$.ha ${ }^{-1}$ (Z. mucronata). Cette étude confirme l'efficacité in vitro des extraits aqueux des plantes testées dans le contrôle des cercosporioses 
précoce et tardive de l'arachide. Par conséquent, leur utilisation dans le contrôle des cercosporioses pourrait conduire à des augmentations substantielles de rendement pour les producteurs tout en assurant des conditions plus sûres pour les consommateurs, les producteurs et l'environnement.

Mots Clés: Arachide, Cercospora arachidicola, extraits de plantes, maladies fongiques, Phaeoisariopsis personata.

\section{INTRODUCTION}

Groundnut (Arachis hypogaea L.) is the sixth most important oilseed crop in the world. Among the fungal diseases of groundnut, leaf spot (early and late leaf spots) is a major constraint in its production in Tropical Africa. During severe disease outbreaks, leaf spot, in addition to rust can result in yield losses up to 50\% (Ghewande, 2009).

Diseases arising in the field are not usually controlled; however, they are controlled with synthetic fungicides that often pollute the environment and threaten human health. Thus, finding alternative control measures has become a major research objective. So, far, the antimicrobial properties of plant extracts has shown higher prosperts for becoming an alternative to synthetic fungicides (Deberdt $e t$ al., 2012; Malkhan et al., 2012; Bakeer et al., 2015).

Plants contain a wide stock of biochemical substances having antifungal properties. Their utilisation is less detrimental to the environment than synthetic pesticides (Hashim and Devi, 2003). Aqueous extracts of Cymbopogon citratus, Cassia occidentalis, Balanites aegyptiaca and Portulaca oleracea inhibited growth of mycelia of Colletrotrichum graminicola and Phoma sorghina, which are pathogenic fungi of sorghum seeds (Bonzi $e t$ $a l .$, 2012). Likewise, extracts of leaves of papaya tree (Carica papaya L.) and vernonia (Vernonia amygdalina Delile) were successfully tested against pathogenic fungi of groundnut (Ogwulumba et al., 2008). Other research efforts recommended the use butanol extracts of Carica papaya and Azadirachta indica to control fungal diseases of Gmelina arborea Roxb (Johnson et al., 2014).
Recent research revealed that aqueous extracts of Agave sisalana contained antifungal properties against fungal pathogens of rice (Magnaphorte grisae) (Kassankogno et al., 2015). Another study confirmed a positive effect of extracts of Azacdiractha indica on the inhibition of many fungal growths such as in Alternaria alternata, Bipolaris sorokiniana, Fusarium oxyporium and Helmonthosporium sp. (Al Hazim, 2013). Extract of Capsicum frutescens $\left(10 \mathrm{mg} \mathrm{ml}^{-1}\right)$ was also effective in controlling groundnut seed pathogens such as Aspergillus niger, A. flavus, Penicillium sp. and Rhizopus sp. (Soumya and Bindu, 2012). Palm wine was successfully used to protect yam (Dioscorea spp.) (Assiri et al., 2010) against Botryodiplodia sp., Penicillium sp. ; Aspergillus sp., Mucor sp. and Colletotrichum sp. fungi causing rots in yam tubes. Similarly, the growth of pathogenic fungi (Fusarium moniliforme, Curvularia lunata, Colletotrichum graminicola, Exserotrilum rostratum) of sorghum and millet seeds was inhibited by aqueous extracts of Acacia gourmaensis A. Chev. and Eclipta alba (L.) Hassk. Inhibition rates of 27-72 and 56-86\%, respectively, were observed for the protection of sorghum and millet seeds against the previous pathogens (Zida et al., 2008).

In Burkina Faso, an in vitro study proved that extracts of four native plants were efficacious against Cercospora arachidicola Hori., Phaeoisariopsis personata (Berk et Curt) and Puccinia arachidis; which are the respective causal agents of early leaf spot, late leaf spot and rust of groundnut (Kö̈ta et al., 2010; Koïta et al., 2012). Despite their in vitro efficacy to inhibit fungal growth or germination, plant extract potential under field conditions is still insufficiently exploited due to deficiency of reliable studies on this subject. 
The objective of this study was to investigate the efficacy of aqueous extracts from Lippia multiflora Moldenke, Boscia senegalensis (Pers.) Lam, Ziziphus mucronata Willd. and Securidaca longepedonculata $\mathrm{L}$. to control early and late leaf spot of groundnut.

\section{MATERIALS AND METHODS}

Study site. This study was conducted in Gampela district, located at longitude $12.22^{\circ} \mathrm{W}$ and latitude $12.25^{\circ} \mathrm{N}$ of Ouagadougou in Burkina Faso. The annual temperature ranged between 21.5 and $42.8^{\circ} \mathrm{C}$. Treatments involved four aqueous plant extracts, and two controls (negative and positive).

Treatments and design. The test was conducted on the groundnut variety TS32-1 resulting from a cross between varieties spantex and TE3. TS32-1 is the recommended variety by the National Institute of Agricultural Research of Burkina Faso (INERA). TS32-1 is an early maturing (90 days) variety and it is widely cultivated in Burkina Faso. However, TS32-1 is susceptible to early and late leaf spots, rust, rosette and aspergillus flavus (Subrahmanyam and Hildebrant, 1992). The fungicidal properties of four native plant species of Burkina Faso was evaluated by applying their aqueous extracts on this susceptible groundnut variety. Plant extract was obtained from leaves of Boscia senegalensis Pers. (collected from north of Burkina), root bark of Securidaca longepedunculata L.), leaves of Lippia multiflora Moldenke and fruits of Ziziphus mucronata Will. (collected of middle of Burkina).

These six treatments were laid out in a randomised complete block design, in three replicates. Row to row distance was $1 \mathrm{~m}$; while from plant to plant distance was $15 \mathrm{~cm}$.

The trial was repeated two times (2011 and 2012). No plant extract was applied to the negative control plot. Fungicide, benlate (activer 50\%: benomyl) was used in the positive control. A fertiliser composed of 14 23-14, nitrogen- phosphorus - potassium ( $\mathrm{N}$ P-K) was applied at a rate of $100 \mathrm{~kg} \mathrm{ha}^{-1}, 21$ days after sowing (DAS).

Phytoextracts preparation. The root bark of Securidaca longepedunculata was used in its fresh state, by keeping the harvested part at, $8{ }^{\circ} \mathrm{C}$ prior to extraction; while leaves and fruits of the other plants species were dried in shade at room temperature $\left(25\right.$ to $30{ }^{\circ} \mathrm{C}$ ). Leaves of Lippia multiflora and of Boscia senegalensis were ground into powder with a hand-held mill. The powder was preserved in a dry and cool place in the laboratory.

The fruits of Ziziphus mucronata were pounded in a manual seed grinder, before the pulp was separated from the seed. It was kept in a dry and cool place in the laboratory in order to preserve the active ingredients of the product. About $50 \mathrm{~g}$ of each plant tissue (leaves powder, pulp of the fruit or roots bark) were mixed with $1000 \mathrm{ml}$ of distilled water for the preparation of the aqueous extracts. This quantity was applied to a block of $12 \mathrm{~m}^{2}$, which was a rate of $4.166 \mathrm{~kg}$ per hectare as used in previous studies (Koïta et al., 2010; Koïta et al., 2012). The mixture was shaken for about 20 minutes and then filtered through smooth mesh linen.

Field treatment. Plants were sprayed with aqueous extracts using a hand-held Solo branded sprayer. Spraying was done on the basal leaves which were diseased before the upper ones. Individual plants were sprayed until the quantity of extracts prepared for a treatment was exhausted. Treatments were applied in the mornings between 6 and 9a.m to avoid the heat that could affect the stability of the extract. Spraying was carried out four times at 15 days interval for both years of experimentation starting at 25 days after sowing (DAS)and latest at70DAS.

Data collection and statistical analysis. Disease severity was recorded biweekly, 
starting at $25^{\text {th }} \mathrm{DAS}$, ending at 85 DAS. Using the ICRISAT scale, which ranges from 1 to 9 (Subrahmanyam et al., 1995), disease scores were recorded depending on visual estimation of necrosis and defoliation. Where $1=$ no disease, $2=$ lesions present on lower leaves with no defoliation, 3 to 8 associated with increasing levels of defoliation and necrosis and $9=$ defoliation of almost all leaves leaving bare stems, with any leaflets present having many leaf spots. From the scores, the percentage of necrotic area was calculated by using the following formula (Narh et al., 2014):

10

Necrosis $(\%)=1.36 \mathrm{x}----\mathrm{x}$ IS -1.45

9

Where: IS $=$ ICRISAT visual score

Besides the necrotic area, defoliation was also estimated at 85DAS, which was the maximum defoliation stage (Subrahmanyam et al., 1995). This record was taken on the main stems of five plants chosen for each treatment. The percentage of defoliation was derived from the ratio between the number of dropped leaves and total number of sprouted leaves.

Pod yield and 100 seed weight were also evaluated after harvesting for each plot. To ensure homogeneity of variances and normality of the distribution of each variable, data recorded as percentages were arcsinetransformed before analysis of variance (ANOVA). Statistical analysis were done with the software XLSTAT-2010. Treatment means were compared using Student Newman-Keul test.

\section{RESULTS}

Disease assessment. Data for leaf spot disease progression and percent necrosis are presented in the Table 1. All plant extracts significantly $(\mathrm{P}<0.05)$ reduced the severity of Cercospora arachidicola and of Phaeoisariopsis personata on groundnut leaves. The negative control plot recorded the highest disease severity score of 8.1 on a 9 point scale (ICRISAT scale) corresponding to a high attach level. Aqueous extract of $L$. multiflora recorded the lowest diseases severity score (3.7) among the four plant species. Its score was statistically lower than extracts of the remaining three plants but similar to the score (3.7).

A higher level of necrosis $(9.3 \%)$ was registered in the negative control plot (Table 1). On the other hand, treated plots showed slower disease progression with a rate of $6 \%$. Among the plots treated, L. multiflora recorded the lowest leaf percentage necrotised with a $4.1 \%$ score. This value is close to the fungicide control, with a value of $3.3 \%$ of necrotic leaf area.

The effects of the fungicide and plants extracts on defoliation are shown in Figure 1. All plant extracts controlled the defoliation to significant level compared to negative control, which recorded the highest defoliation rate $(57.05 \%)$. This was followed by three plots treated with aqueous extracts of $S$. longepedunculata $(47.59 \%)$, B. senegalensis $(44.05 \%)$ and Z. mucronata $(42.22 \%)$. Among the plots treated with plant extracts, L. multiflora recorded the best control of

TABLE 1. Disease progression (ICRISAT score) and percent necrosis causant by leaf spot regarding treatment applied in experimental field in Gampêla district in Burkina Faso

\begin{tabular}{lcc}
\hline Treatment & $\begin{array}{c}\text { Disease } \\
\text { score }\end{array}$ & $\begin{array}{c}\text { Necrotic } \\
\text { leaf area }(\%)\end{array}$ \\
\hline S.longepedunculata & $4.9^{\mathrm{b}}$ & $6.0^{\mathrm{b}}$ \\
B.senegalensis & $4.8^{\mathrm{b}}$ & $5.9^{\mathrm{c}}$ \\
Z. mucronata & $4.3^{\mathrm{b}}$ & $5.0^{\mathrm{c}}$ \\
L. multiflora & $3.7^{\mathrm{c}}$ & $4.1^{\mathrm{d}}$ \\
Negative control & $8.1^{\mathrm{a}}$ & $9.3^{\mathrm{a}}$ \\
Fungicide & $3.4^{\mathrm{c}}$ & $3.3^{\mathrm{e}}$ \\
\hline
\end{tabular}

Mean with similar alphabetical superscript are not significantly different $(\mathrm{P}=0.05)$ by Newman-Keul's test 
defoliation $(37.13 \%)$. The fungicide plot recorded $23,73 \%$ which was the lowest defoliation.

Pod yield. The effect of plant extracts on pod yield are shown in Figure 2. The aqueous extracts from all the four plant species, $S$. longepedunculata, $B$. senegalensis, $Z$. mucronata and L. multiflora increased pod yield over pod yield of the negative control
(1226.074 $\left.\mathrm{kg} \mathrm{ha}^{-1}\right)$. Lippia multiflora and Z. mucronata extracts treated plots recorded the highest pod yield among the four plant extracts, and its pod yield was significantly higher than that of $B$. senegalensis and $S$. longepedunculata. With regards to the control, the extract of L. multiflora and Z. mucronata had product in excess of more than $900 \mathrm{~kg}$ ha $^{-1}$.

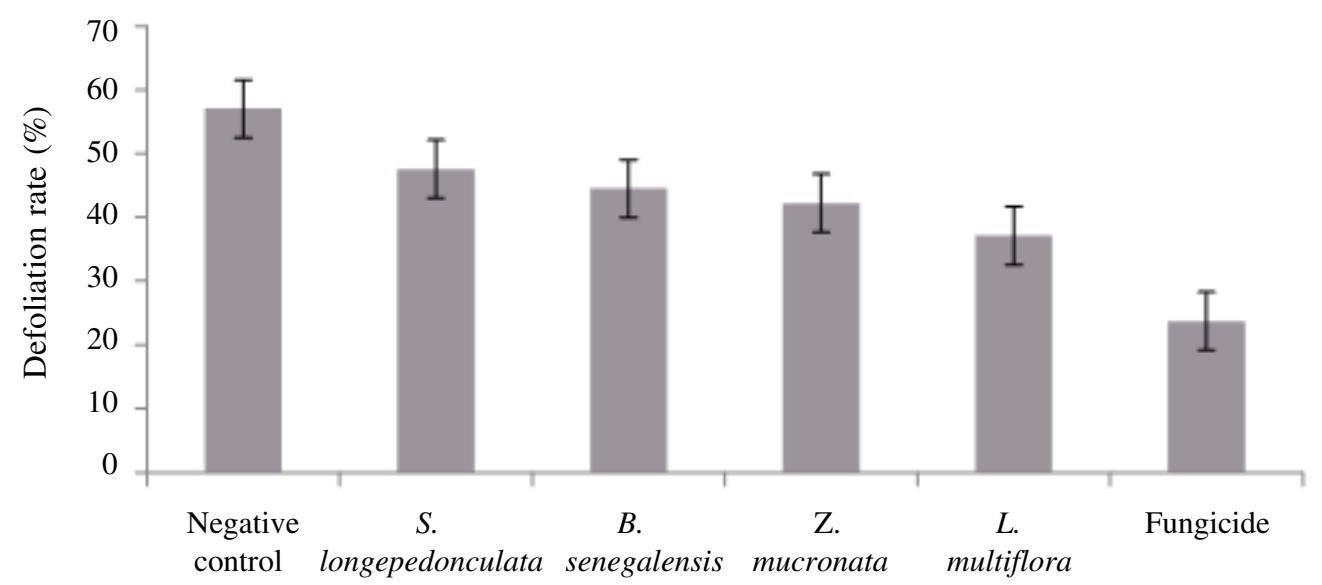

Treatments

Figure 1. Effect of plant extracts and controls on defoliation rate in experimental field in Gampêla district in Burkina Faso.

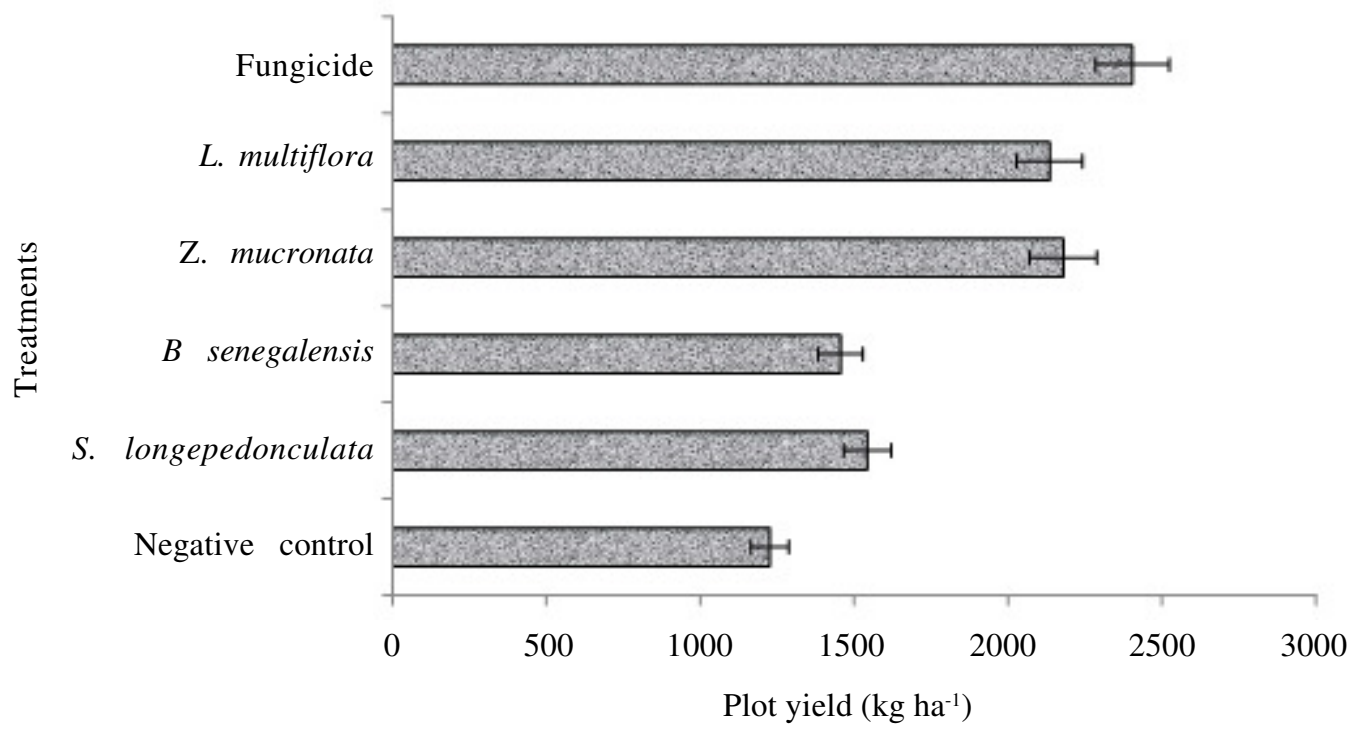

Figure 2. Effect of plant extracts on pod yield regarding treatment applied in experimental fieldin Gampêla district in Burkina Faso. 
TABLE 2. Values of 100 seed weight $(\mathrm{g})$ obtained from the six treatmentsin two cropping seasons in Gampêla district in Burkina Faso

\begin{tabular}{lc}
\hline Treatment & 100 seed weight $(\mathrm{g})$ \\
\hline Negative control & $29.84^{\mathrm{c}}$ \\
S. longepedunculata & $33.52^{\mathrm{b}}$ \\
B. senegalensis & $34.27^{\mathrm{b}}$ \\
Z. mucronata & $35.45^{\mathrm{b}}$ \\
L. multiflora & $34.93^{\mathrm{b}}$ \\
Fungicide & $37.29^{\mathrm{a}}$ \\
\hline
\end{tabular}

Means with similar alphabetical superscript are not significantly different $(\mathrm{P}=0.05)$ by Newman-Keul's test

100-seed weight. Aqueous extracts of all four plant species significantly increased 100-seed weight (Table 2). Although, the positive control (fungicide) yielded the highest 100-seed weight with $37.29 \mathrm{~g}$. The 100-seed weight from extracts of the four plant species were similar $(\mathrm{P}>0.05)$ and varied around $34 \mathrm{~g}$.

\section{DISCUSSION}

Disease assessment. The low disease severity scores recorded for plots treated with plant extracts (Table 1) prove the capacity of these extracts to inhibit early and late leaf spot development under field conditions. The negative control plot recorded the highest severity score of and percent necrosis. This confirms in vitro antifungal activity of these plants previously observed on C. arachidicola and $P$. personata(Koïta et al., 2010) and Puccinia arachidis (Koïta et al., 2012). Other studies have been reported the antifungal activity of extracts from other plant species. Insecticidal activity of Boscia senegalensis on the groundnut bruchid (Caryedon serratus) was reported by Gueye et al. (2011). On the other hand, efficacy of $B$. senegalensis extracts in the field against $C$. arachidicola and $P$. personata was confirmed by Karimou (1999). Several studies were carried out on the biological activities of essential oil of Lippia genus. Tatsadjieu et al. (2009) noted the total inhibition of radical growth of Aspergillus flavus by essential oil of L. rugose. Besides, efficacy of essential oil of $L$. rehmannii against some fungi including Rhizoctonia solani, Fusarium oxysporum and Penicillium digitatum pathogens of potato, maize and orange tree respectively have been reported by Linde $e t$ al. (2010). Owolabi et al. (2009) revealed a strong bactericide activity of the essential oils of L. multiflora against Bacillus cereus, Staphylococcus aureus and Escherichia coli. On the other hand, this report confirms the use of aqueous extracts of $S$. longepedunculata, L. multiflora and $Z$. mucronata to succesfully control early and late leaf spots of groundnut under field conditions. The fungi and rust involved in the present study have shown sensitivity toother plant extracts; for instance, successful inhibition of spore germination (greater than $90 \%$ ) of these fungi was achieved with oils of cinnamon bark (Cinnamomum cassia), clove (Syzygium aromaticum) and essential oil of citronella (Cymbopogon citratus) (Kishore et al., 2007). Other studies showed that aqueous and ethanol leaf extracts of Datura metel, Lawsonia inermis and Sphaeranthus indicus at $25 \%$ concentration completely inhibited the conidial germination of $P$. personata (Kishore et al., 2001). Chloroform extract of Hemionitis arifolia was found to be highly efficacious (inhibition rate $>70 \%$ ) against $P$. arachidis and $P$. personata (Sahayaraj et al., 2009).

Pod yield. Management of leaf spotswith plant extracts in the field has been evaluated by Krishna and Pande (2005). Thus, they reported that foliar application of Prosopis juliflora extract effectively reduced groundnut foliar disease severity and increased the pod yield. The present study identified $P$. juliflora extract as a significant component for the integrated management of groundnut foliar diseases. Late leaf spotof groundnut was also controlled in the field using neem seed, black soap and cow 
dung (Alabi and Olorunju, 2004). Another study revealed that foliar application of panchgavya and neem leaf extract recorded significant improvement in different parameters of chlorophyll content, nitrate reductase activity, root nodule weight, leaf area index, dry matter accumulation, nutrient content and uptake of groundnut and pod yield (Kumawat et al., 2009).

Papaya leaf extracts used against leafy disease of groundnut considerably reduced disease incidence to $2.20 \%$ from $74.74 \%$ (Ogwulumba et al., 2008). Shakil et al. (2012) conducted experimental tests in which aqueous extracts of the leaves of Calotropis procera were as effective as fungicide (Ridomil) in the control of collar decay of groundnut. Calotropis procera treatment recorded a pod yield of $1,065 \mathrm{~kg} \mathrm{ha}^{-1}$, compared to $1032 \mathrm{~kg} \mathrm{ha}^{-1}$ pod yield for plot treated with fungicide(Ridomil).

100-seed weight. The weight of 100 seeds, is a value that determines the correct filling of the seeds. This requires a good photosynthetic activity. For this purpose the peanut plant must keep its leaves.For this purpose the peanut plant must keep its leaves. Strong defoliation necessarily results in poor seed filling, low weight of 100 seeds and low yield.

\section{CONCLUSION}

The present study confirms the efficacy of aqueous extracts of four local plant species (S. longepedunculata, B. senegalensis, $Z$. mucronata and L. multiflora) to control pathogenic fungi involved in early and late leaf spots diseases of groundnut. Among the tested species, aqueous extracts of $L$. multiflora gives the highest pod yields followed by $Z$. mucronata and $S$. longepedunculata, respectively. These results require further investigations to understand the exact mode of reaction of these extracts. A chemical screening study would help to high light the characteristic fungicidal molecules of these species through the isolation and identification of actives molecules.

\section{ACKNOWLEDGEMENT}

We thank the International Foundation for Science (IFS) whose financial support allowed the realisation of this work.

\section{REFERENCES}

Al Hazim, R.H.M. 2013. Effect of neem (Azadirachta indica) leaves and seeds extracts on the growth of six of the plant diseases causing fungi. Global Advanced Research Journal of Microbiology 2(5): 089-098.

Alabi, O. and Olorunju, P.E. 2004. Evaluation of neem seed extract, black soap and cow dung for the control of groundnut leaf spot at Samaru, Nigeria. Archives of Phytopathology and Plant Protection 37(2):123-127.

Assiri, P.K., Diallo, H.A. and Ake, S. 2010. Evaluation du potentiel antifongique du vin de palme contre les champignons responsables de pourritures des tubercules d'igname (Dioscorea spp) pendant le stockage au champ. Journal of Applied Biosciences 29:1753-1765

Bakeer, A.T., Khaled Elbanna, K. and Elnaggar, S.A. 2015. Impact of pre- and post-harvest applications of natural antimicrobial products on apple and pear soft rot disease. International Journal of Phytopathology 04(03):105-119.

Bonzi, S., Somda, I., Zida, E.P. and Sereme, P. 2012. In vitro antifungal activity of various local plant extracts in the control of Phoma sorghina (Sacc.) Boerema et al. and Colletotrichum graminicola (Ces.) Wilson, as Sorghum Seed Mold Pathogen in Burkina Faso. Tropicultura 30 (2):103106.

Deberdt, P., Perrin, B., Coranson-Beaudu, R., Duyck, P.F. and Wicker, E. 2012. Effect of Allium fistulosum extract on Ralstonia 
solanacearum populations and tomato bacterial wilt. Plant Disease 96:687-692.

Ghewande, M.P. 2009. Early and late leaf spots of groundnut and their management. In Integrated pests and disease management. Eds. Mukerji Rajeev K.G., Upadhyay H., Chamola B. P., Dueby O.P. APH Publishing Corporation. New Dehli, India. pp. 326334.

Gueye, M.T. Seck, D. Ba, S. Hell, K. Sembene, M. Wathelet, J.P. and Lognay, G. 2011. Insecticidal activity of Boscia senegalensis (Pers.) Lam ex Poir. on cayedon serratus (OI) pest of stored groundnuts. African Journal of Agricultural Research 6(30): 6348-6353.

Hashim, M.S. and Devi, K.S. 2003. Insecticidal action of the polyphenolic rich fraction from the stem barks of Sterlus asper on Dysdercus cingulatus. Fitoterapia 74: 670-676.

Johnson, U.E., Akwaji, P. I., Aniedi-Abasi, M., Effiong, U.S. and Effiom, O.E. 2014. Phytochemical composition, antimicrobial effect of Azadirachta indica and Carica papaya extracts on fungi isolated from gmelina arborea seedlings. International Journal of Phytopathology 03(03):109-115.

Karimou, I. 1999. Effets des extraits des essences ligneuses sur le développement des cercosporioses de l'arachide (Arachis hypogaea L.) au Niger. Degree of Diplôme d'Etudes Approfondies (DEA). University of Ouagadougou 03 BP 7021 Ouagadougou 03, Burkina Faso. 69pp.

Kassankogno, A.I., Ouedraogo, I., Tiendrebeogo, A., Ouedraogo, L. and Sankara, P. 2015. In vitro evaluation of the effect of aqueous extracts of Agave sisalana and Cymbopogon citratus on mycelial growth and conidia production of Pyricularia oryzae, causal agent of rice blast. Journal of applied Biosciences 89: 8272-8280.

Kishore, G. K., Pande, S. and Rao, J. N. 2001. Control of late leaf spot of groundnut (Arachis hypogaea) by extracts from non- host plant species. Plant Pathology Journal 17 (5):264-270.

Kishore, G. K., Pande, S. and Harish, S. 2007. Evaluation of essential oils and their components for broad-spectrum antifungal activity and control of late leaf spot and crown rot diseases in peanut. Plant Disease 91:375-379.

Koïta, K., Neya, B. F., Nana, T. A., Zagre, M. B. and Sankara, P. 2010. Etude de l'efficacité d'extraits végétaux dans la lutte contre Cercospora arachidicola et Phaeoisariopsis personata (Berk et Curt.) au Burkina Faso. Annals of Ouagadougou University. 008 : 94-115.

Koïta, K., Neya, B.F., Nana, T.A. and Sankara, P. 2012. Activité antifongique d'extraits de plantes locales du Burkina Faso contre Puccinia arachidis Speg., agent pathogène de la rouille de l'arachide (Arachis hypogaea L.). Journal of applied Biosciences 57:4142-4150.

Krishna, G. K. and Pande, S. 2005. Integrated management of late leaf spot and rust diseases of groundnut (Arachis hypogaea L.) with Prosopis juliflora leaf extract and chrorothalonil. International Journal of Pest Management 51(4):325-332.

Kumawat, R.N., Mahajan, S.S. and Mertia, R.S. 2009. Growth and development of groundnut (Arachis hypogaea) under foliar application of panchgavya and leaf extracts of endemic plants. Indian Journal of Agronomy 54(3):324-331.

Linde, J. H., Combrinck, S., Regnier, T.J.C. and Virijevic, S. 2010. Chemical composition and antifungal activity of the essential oils of Lippia rehmannii from South Africa. South African Journal of Botany 76:37-42.

Malkhan, S.G., Shahid, A., Masood, A. and Kangabam, S. 2012. Efficacy of plant extracts in plant disease management. Agricultural Sciences 3(3):425-433.

Narh, S., Boote, K.J., Naab, J.B., Abudulai, M., Zagre, M.B. and Sankara, P. 2014. Yield improvement and genotype $\times$ environment 
analyses of peanut cultivars in multilocation trials in West Africa. Crop Science 54:24132422.

Ogwulumba, S.I., Ugwuoke, K.I. and Iioba, C. 2008. Prophylactic effet of paw-paw leaf and bitter leaf extracts on the incidence of foliar mycopathogens of groundnut (Arachis hypogaea L.) in Ishiagu, Nigeria. African Journal of Biotechnology 7: 28782880.

Owolabi, M.S., Ogundajo, A., Lajide, L., Oladimeji, M.O., Setzer, W.N., Palazzo, M.C. 2009. Chemical composition and antibacterial activity of the essential oil of Lippia multiflora Moldenke from Nigeria. Records of Natural Products 3(4):170-177.

Sahayaraj, K., Borgio, J.A.F. and Raju, G. 2009. Antifungal activity of three fern extracts on causative agents of groundnut early leaf spot and rust diseases. Journal of Plant Protection Research 49(2):1411144.

Shakil, A., Noor, Z. and Salik, N.K. 2012. Management of root rot disease of groundnut (Arachis hypogeae L.) by plant extracts. African Journal of Microbiology Research 6 (21):4489-4494.

Soumya, S.L. and Bindu, R.N. 2012. Antifungal efficacy of Capsicum frutescens L. extracts against some prevalent fungal strains associated with groundnut storage.
Journal of Agricultural Technology 8 (2):739-750.

Subrahmanyam, P., McDonald, D., Waliyar, F., Reddy, L.J., Nigam, S.N., Gibbons, R.W., Ramanatha, V., Rao, Singh, A.K., Pande, S., Reddy, P.M. and Subba Rao, P.V. 1995. Screening methods and sources of resistance to rust and late leaf spot of groundnut. ICRISAT Information Bulletin No. 47. ICRISAT, Patancheru Andhra Pradesh, India.

Subrahmanyam, P. and Hildebrant, G.L. 1992. Compte rendu de la troisième réunion de l'ICRISAT sur l'arachide en Afrique de l'Ouest. 14-17 Sept. Ouagadougou, Burkina Faso. Patancheru, A.P. 502324. India : ICRISAT, 99p.

Tatsadjieu, N.L., Jazet Dongmo, P.M., Ngassoum, M.B., Etoa, F.X. and Mbofung, C.M.F. 2009. Investigations on the essential oil of Lippia rugosa from Cameroon for its potential use as antifungal agent against Aspergillus flavus Link ex. Fries. Food Control 20(2):61-166.

Zida, P.E., Sereme, P., Leth, V. and Sankara, P. 2008. Effect of aqueous extracts of Acacia gourmaensis A. Chev. and Eclipta alba (L.) Hassk. on seed health, seelding vigour and Grain yield of sorghum and pearl millet. Asian Journal of Plant Pathology 2 (1):40-47. 